\title{
Tissue Culture Studies on Propagation of Some Ornamental Plants 1. Starting and Shooting Stages of Phytolacca dioica $\mathbf{L}$. El-Afry, M. M. ${ }^{1}$; E. S. Nofal ${ }^{2}$; F. M. Saadawy ${ }^{3}$ and G. A. M. Omera ${ }^{3}$ \\ ${ }^{1 .}$ Agric. Botany Dept., Fac. Agric, Kafr El-Sheikh Univ. \\ 2. Plants, Hort. Dept., Fac. Agric, Kafr El-Sheikh Univ. \\ 3. Ornamental Plants Res. Dept., Hort. Res. Inst., Agric Res. Center.
}

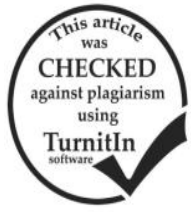

\section{ABSTRACT}

This work was carried out in the Tissue Culture Laboratory, Horticulture Research Institute, Agricultural Research Center, Giza, Egypt from the period elapsed from 2014 to 2016 to study the effect of sterilization on propagation of Phytolacca dioica, L. Results of this study could be briefed in the following outlines: Chlorox concentrations at 30 or $35 \%$ gave the highest survival percentage of Phytolacca dioica, L.. In addition, soaking explants in the sterilant solution for 20 or 25 minutes resulted in the highest survival percentage. Similarly, the interaction treatment demonstrated that using chlorox at $35 \%$ for 25 minutes resulted in the highest survival\%. In the multiplication stage it was found that using BAP at $10 \mathrm{ppm}$ resulted in the highest number of shoots and leaves. BAP at 6 or $8 \mathrm{ppm}$ induced the highest content of total chlorophyll. The longest shoots were a result of applying BAP at $3 \mathrm{ppm}$. Inoculating explants on half strength medium resulted in the highest values of number of shoots and leaves, as well as highest contents of total chlorophyll and carotenoids. MS medium at 3 quarters strength shared in the first position of number of leaves. The longest shoots were a result of using MS medium at full strength. The interaction between BAP levels and MS medium strength, indicated that using MS medium at half strength supplemented with BAP at 10 ppm produced highest number of shoots. The same medium strength with BAP at 8 or $6 \mathrm{ppm}$ gave the highest contents of total chlorophyll and carotenoids. MS medium at 3 quarters strength combined with PAP at $10 \mathrm{ppm}$ gave highest number of shoots and leaves. MS medium at full strength plus BAP at either 3 or 10 ppm resulted in the highest shoot length and number of leaves.

\section{INTRODUCTION}

Genus of Phytolacca: (family Phytolaccaceae) is a perennial dicotyledonous plants native to North America, South America, East Asia and New Zealand. Some members of the genus are known as pokeweeds or similar names such as pokebush, pokeberry, pokeroot or poke sallet. Other names for species of Phytolacca include inkberry and ombú, (InterNet Site 1, 2016).

Phytolaccatoxin and phytolaccigenin are present in many species which are poisonous to mammals if not cooked properly. However, the berries are eaten by birds, which are not affected by the toxin because the small seeds with very hard outer shells remain intact in the digestive system and are eliminated whole, (InterNet Site 1, 2016).

The genus comprises about 25 to 35 species of perennial herbs, shrubs, and trees growing from 1 to $25 \mathrm{~m}$ tall. They have alternate simple leaves, pointed at the end, with entire or crinkled margins; the leaves can be either deciduous or evergreen. The stems are green, pink or red. The flowers are greenish-white to pink, produced in long racemes at the ends of the stems. They develop into globose berries 4-12 mm diameter, green at first, ripening dark purple to black.

Although many species are herbaceous, Phytolacca dioica, $\mathrm{L}$ forms a substantial tree native to subtropical South America. It grows as a tree on the pampas of South America and is one of the few providers of shade on the open grassland. This species has massively buttressed bases to its trunk, and very soft wood with a high water storage capacity which makes them resistant to grass fires and drought, (InterNet Site 1, 2016)

There are only three specimens of Phytolacca dioica, L. in Egypt, the first in Zohryi Garden, the second in Orman Garden and the third in Giza Zoo. This may indicate the importance of micropropagating this plant da Silva et al. (2015) declared that explant disinfection is the first and most challenging step of establishing an aseptic culture and is therefore a prerequisite for the successful tissue culture of any plant. During disinfection, all microorganisms such as bacteria or fungi that contaminate the explant exogenously and endogenously have to be removed, without destroying and killing the plant tissues. Since disinfection agents used for surface disinfection of explants can also be toxic to plant tissues, a balance between the level of contamination and explant survival should always be considered when using disinfection agents. In the same concern, Khatun et al. (2016) stated that during micropropagation, surface sterilization is the most important step in preparation of explants.

Surface sterilization of plant material may be accomplished with an aqueous solution of either sodium hypochlorite $(\mathrm{NaOCl})$ or calcium hypochlorite $\left(\mathrm{Ca}(\mathrm{OCl})_{2}\right)$. Most workers use common household bleach such as clorox. These commercial products contain about $5 \% \mathrm{NaOCl}$ as the active agent. These are usually used at concentrations from $10-20 \%$ (v/v) i.e. containing about $0.5-1.0 \% \mathrm{NaOCl}$. This concentration is adequate for the surface sterilization of explants. However, higher levels are often used, Dodds and Roberts (1995).

George et al. (2008) reported that plant tissues and organs are grown in vitro on artificial media, which supply the nutrients necessary for growth. The most commonly used medium is the formulation of Murashige and Skoog (1962). This medium was developed for optimal growth of tobacco callus. Comparing MS to the elementary composition of normal, well-growing plants, they stated that the relatively low levels of $\mathrm{P}, \mathrm{Ca}$ and $\mathrm{Mg}$ in $\mathrm{MS}$ are evident. The most striking differences are the high levels of $\mathrm{Cl}$ and $\mathrm{Mo}$ and the low level of $\mathrm{Cu}$. Plant tissue culture 
media provide not only inorganic nutrients, but usually a carbohydrate (sucrose is most common) to replace the carbon which the plant normally fixes from the atmosphere by photosynthesis. To improve growth, many media also include trace amounts of certain organic compounds, notably vitamins, and plant growth regulators.

Groll et al. (2002) compared quarter-, half-, fullor double-strength MS media on cassava (Manihot esculenta). They mentioned that the maximum number of somatic embryos differentiated from a proliferative nodular embryogenic callus on either half- or full-strength MS medium, and the greatest numbers of cotyledonary stage embryos were formed on full-strength MS medium. Mukherjee et al. (2010) proved that shoot proliferation of grape rootstock increased when cultured on MS with half of nitrate component. Mustafa et al. (2013) studied the effect of different strengths of MS medium, double, full, half and quarter strengths on in vitro multiplication of two fig cultivars. They found that double strength MS medium obviously enhanced number of leaves and shoot length. However, the highest values of shoot number were observed with full MS medium. Fakhrul et al. (2014) stated that macronutrients manipulation in MS media could affect the growth of Stevia rebaudiana. Rezali et al. (2016) claimed that in plant tissue culture, media composition is the determining factor that influences plant growth.

The effect of cytokinins is most noticeable in tissue cultures where they are used to stimulate cell division and control morphogenesis. When added to shoot culture media, they overcome apical dominance and release lateral buds. The effect of cytokinins is most noticeable in tissue cultures where they are used to stimulate cell division and control morphogenesis, (George, 1993 and George et al., 2008). Kanwar et al. (2013) stated that cytokinins promote shoot proliferation by inducing cell division and enlargement.

Therefore, the present, aimed to investigation evaluate different materials and methods for starting and shooting stages of Phytolacca dioica, L. micropropagating.

\section{MATERIALS AND METHODS}

The terminal $20 \mathrm{~cm}$ end of newly grown shoots was cut from Phytolacca dioica, L. tree in Zohryia Garedn in April. These segments were taken to the Tissue Culture Lab in the same place where they were thoroughly washed with tap water and soap for 30 minutes to rid them of dust and debris before being defoliated. Lateral buds were excised, used as an explants and distributed into different jars where they were subjected to a combination of five chlorox levels $(20,25,30,35$ and $40 \%)$ and exposure time $(5,10,15$, 20 and 25 minutes) in a factorial experiment under completely randomized block design system . At the end of each treatment bud explants were removed and rinsed with distilled sterilized water for 4 times. These treatments were consummated under aseptic conditions in the laminar air flow hood. Buds of each treatment were divided into three replicates; each comprised 8 jars in which they were inoculated on $1 / 2$ MS medium supplemented with BAP at $2 \mathrm{ppm}$. Two weeks later, survival percentages were calculated for each replicate.

Buds that survived sterilization and were contamination-free were used in a multiplication experiment, where two factors were adopted. The first factor was BAP levels (0, 1, 2, 3, 4, 5, 6, 8 and $10 \mathrm{ppm})$ and the second one was strength of MS medium (half, three quarters and full strength) in a factorial experiment under completely randomized block design system. One month later, number of shoots and leaves, shoot length and total chlorophyll content according to Saric et al. (1967) were recorded.

To statistically test, results of these experiments, excluding those of contents of total chlorophyll and carotenoids, analysis of variance was carried according to Snedecor and Cochran (1989). The means were compared by Duncan's critical range at a probability level of 5\%, Duncan (1955).

Chlorox was purchased from a commercial supermarket.BAP was bought from Technogen Co., a private sector establishment for scientific chemicals, Dokky, Giza.

\section{RESULTS AND DISCUSSION}

\section{Effect of chlorox concentration, exposure time and there interaction on survival\%}

The effect of chlorox concentration on survival\% was significant. Table (1) shows the The highest percentage occurred when chlorox was applied at 30 or $35 \%$ (43.33 and $46.67 \%$, respectively), followed with a significant difference by records obtained when chlorox was used at 40 or $25 \% \quad(34.17$ and $27.50 \%$, respectively). The lowest value in this concern was a result of using chlorox at $20 \%(22.50 \%)$.

Moreover, the effect of exposure time on survival\% was significant. The same table shows that highest survival\% was obtained when explants were exposed to chlorox for 20 or 25 minutes $(49.17 \%$ for both treatments). The lowest survival\% resulted when exposure time was confined to 5 minutes only (13.33\%).

As for the interaction treatment, it was observed that the highest survival\% was a result of using chlorox at $35 \%$ for 25 minutes $(70.83 \%)$, while the lowest one was induced when chlorox at $20 \%$ was applied for 20 minutes $(4.17 \%)$. The results are agreement with those found by Sakr et al. (2011) who soaked explants of Cerbera odollam (Apocynaceae) in chlorox solution at the rate of $10,15,20$ and $25 \%$, for 15,20 and $25 \mathrm{~min}$. They found that chlorox at $20 \%$ gave the highest value of explant survival\%. Increasing exposure time decreased the survival\%. The interaction between chlorox concentration and exposure time indicated that the best survival\% was observed when shoot tip explants were immersed in $20 \%$ chlorox for $20 \mathrm{~min}$, and axillary buds in $20 \%$ chlorox for $15 \mathrm{~min}$. Similarly. 
Table 1. Effect of chlorox concentration, exposure time and their interaction on survival\%

\begin{tabular}{|c|c|c|c|c|c|c|}
\hline $\begin{array}{l}\text { Exposure time } \\
\text { (minutes) }\end{array}$ & 20 & 25 & $\begin{array}{l}\text { Conc. } \\
\text { 30 }\end{array}$ & $\begin{array}{c}(\%) \\
35\end{array}$ & 40 & Mean of time \\
\hline 5 & $4.17 \mathrm{j}$ & $8.33 \mathrm{ij}$ & $12.50 \mathrm{~h}-\mathrm{j}$ & 20.83 gi & $20.83 \mathrm{~g}-\mathrm{i}$ & $13.33 \mathrm{D}$ \\
\hline 10 & $12.50 \mathrm{~h}-\mathrm{j}$ & $20.83 \mathrm{~g}-\mathrm{i}$ & $37.50 \mathrm{~d}-\mathrm{f}$ & $33.33 \mathrm{e}-\mathrm{g}$ & $20.83 \mathrm{~g}-\mathrm{i}$ & $25.00 \mathrm{C}$ \\
\hline 15 & $25.00 \mathrm{f}-\mathrm{h}$ & $25.00 \mathrm{f}-\mathrm{h}$ & $54.17 \mathrm{bc}$ & $45.83 \mathrm{ce}^{\circ}$ & $37.50 \mathrm{~d}-\mathrm{f}$ & $37.50 \mathrm{~B}$ \\
\hline 20 & $37.50 \mathrm{~d}-\mathrm{f}$ & $37.50 \mathrm{~d}-\mathrm{f}$ & $62.50 \mathrm{ab}$ & $62.50 \mathrm{ab}$ & $45.83 \mathrm{c}-\mathrm{e}$ & $49.17 \mathrm{~A}$ \\
\hline 25 & $33.33 \mathrm{e}-\mathrm{g}$ & $45.83 \mathrm{c}-\mathrm{e}$ & $50.00 \mathrm{~b}-\mathrm{d}$ & $70.83 \mathrm{a}$ & $45.83 \mathrm{c}-\mathrm{e}$ & $49.17 \mathrm{~A}$ \\
\hline Mean of conc. & $22.50 \mathrm{C}^{\mathrm{P}}$ & $27.50 \mathrm{BC}^{\prime}$ & $43.33 \mathrm{~A}^{\top}$ & $46.67 \mathrm{~A}^{\prime}$ & $34.17 \mathrm{~B}^{\top}$ & \\
\hline
\end{tabular}

Means with the same letter in the same column are not significantly different

2. Effect of BAP concentration, MS strength and their interaction on shooting stage.

The effect of BAP concentration on number of shoots was significant Table (2) shows the highest number of shoots ( 8.33 shoots) was obtained when BAP at $10 \mathrm{ppm}$ was applied. The second category in the same concern was occupied by BAP at 5,6 or 8 ppm (4.67, 4.78 and 5.22 shoots, respectively). The lowest record (0.89 shoots) was confined to the control treatment (BAP at $0 \mathrm{ppm}$ ).

The same table showed that the effect of MS strength on number of shoots was significant. Higher number of shoots (5.11 shoots) was obtained when inoculating explants on MS medium at half strength, while lower records (3.78 and 2.85 shoots, respectively) were a result of using MS medium at 3 quarters or full strength.

The interaction treatment indicated that the highest number of shoots was induced when BAP at 10 ppm in combination with MS medium at either half or 3 quarters strength were used (12.00 and 10.67 shoots, respectively). On the other hand, using MS medium at half, 3 quarters or full strength, in addition to using BAP at $1 \mathrm{ppm}$ and $\mathrm{MS}$ medium at full strength gave rise to the lowest values in this regard $(1.00,0.67,1.00$ and 1.00 shoots, respectively).

Table 2. Effect of BAP concentration, MS strength and their interaction on number of shoots

\begin{tabular}{|c|c|c|c|c|}
\hline BAP conc. $(\mathrm{ppm})$ & Half & $\begin{array}{l}\text { MS strength } \\
3 \text { quart. }\end{array}$ & Full & $\begin{array}{c}\text { Mean of } \\
\text { BAP conc. }(\mathrm{ppm})\end{array}$ \\
\hline 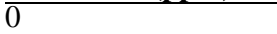 & $1.00 \mathrm{f}$ & $0.67 \mathrm{f}$ & $1.00 \mathrm{f}$ & $0.89 \mathrm{E}$ \\
\hline 1 & $2.00 \mathrm{~d}-\mathrm{f}$ & $2.33 \mathrm{~d}-\mathrm{f}$ & $1.00 \mathrm{f}$ & $1.78 \mathrm{DE}$ \\
\hline 2 & $3.00 \mathrm{c}-\mathrm{f}$ & $2.33 \mathrm{~d}-\mathrm{f}$ & $1.67 \mathrm{ef}$ & 2.33 C-E \\
\hline 3 & $3.67 \mathrm{c}-\mathrm{f}$ & $2.67 \mathrm{c}-\mathrm{f}$ & $3.67 \mathrm{c}-\mathrm{f}$ & 3.33 B-D \\
\hline 4 & $4.33 \mathrm{~b}-\mathrm{e}$ & $2.67 \mathrm{c}-\mathrm{f}$ & $4.67 \mathrm{~b}-\mathrm{e}$ & $3.89 \mathrm{BC}$ \\
\hline 5 & $5.67 \mathrm{bc}$ & $3.33 \mathrm{c}-\mathrm{f}$ & $5.00 \mathrm{~b}-\mathrm{d}$ & $4.67 \mathrm{~B}$ \\
\hline 6 & $7.00 \mathrm{~b}$ & $3.67 \mathrm{c}-\mathrm{f}$ & $3.67 \mathrm{c}-\mathrm{f}$ & $4.78 \mathrm{~B}$ \\
\hline 8 & $7.33 \mathrm{~b}$ & $5.67 \mathrm{bc}$ & $2.67 \mathrm{c}-\mathrm{f}$ & $5.22 \mathrm{~B}$ \\
\hline 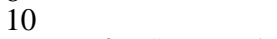 & $12.00 \mathrm{a}$ & $10.67 \mathrm{a}$ & $2.33 \mathrm{~d}-\mathrm{f}$ & $8.33 \mathrm{~A}$ \\
\hline Mean of MS strength & $5.11 \mathrm{~A}^{\top}$ & $3.78 \mathrm{~B}^{\top}$ & $2.85 \mathrm{~B}^{1}$ & \\
\hline
\end{tabular}

Means with the same letter in the same column are not significantly different according to Duncan's multiple range test

Effect of BAP concentration, MS strength and their interaction on shoot length

The effect of BAP concentration on shoot length was significant. Table (3) shows the longest shoots were a result of applying BAP at $3 \mathrm{ppm}(2.16 \mathrm{~cm})$. The second position was occupied by shoots treated wit BAP at 2, 4, 5 and $6 \mathrm{ppm}(1.94,1.90,1.85$ and $1.87 \mathrm{~cm}$, respectively). The shortest shoots were those grown on medium free of BAP $(0.29 \mathrm{~cm})$.

The effect of MS strength on shoot length was significant. Table (3) shows the tallest shoots were a result of using MS medium at full strength, followed without significant difference by those grown on MS

Table 3. Effect of BAP concentration, MS strength and their interaction on shoot length (cm)

\begin{tabular}{|c|c|c|c|c|}
\hline BAP conc. (ppm) & Half & $\begin{array}{l}\text { MS strength } \\
3 \text { quart. }\end{array}$ & Full & $\begin{array}{c}\text { Mean of } \\
\text { BAP conc. }(\mathrm{ppm}) \\
\end{array}$ \\
\hline 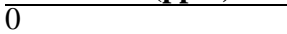 & $1.00 \mathrm{hi}$ & $1.27 \mathrm{e}-\mathrm{i}$ & $0.50 \mathrm{i}$ & $0.92 \mathrm{D}$ \\
\hline 1 & $1.13 \mathrm{~g}-\mathrm{i}$ & $1.40 \mathrm{~d}-\mathrm{h}$ & $2.01 \mathrm{c}-\mathrm{f}$ & $1.51 \mathrm{BC}$ \\
\hline 2 & $1.32 \mathrm{~d}-\mathrm{i}$ & $1.40 \mathrm{~d}-\mathrm{h}$ & $3.09 \mathrm{ab}$ & $1.94 \mathrm{AB}$ \\
\hline 3 & $1.40 \mathrm{~d}-\mathrm{h}$ & $1.46 \mathrm{c}-\mathrm{h}$ & $3.63 \mathrm{a}$ & $2.16 \mathrm{~A}$ \\
\hline 4 & $1.47 \mathrm{c}-\mathrm{h}$ & $2.28 \mathrm{bc}$ & $1.97 \mathrm{c}-\mathrm{g}$ & $1.90 \mathrm{AB}$ \\
\hline 5 & $1.70 \mathrm{c}-\mathrm{h}$ & $2.19 \mathrm{~cd}$ & $1.68 \mathrm{c}-\mathrm{h}$ & $1.85 \mathrm{AB}$ \\
\hline 6 & $2.13 \mathrm{c}-\mathrm{e}$ & $1.88 \mathrm{c}-\mathrm{g}$ & $1.61 \mathrm{c}-\mathrm{h}$ & $1.87 \mathrm{AB}$ \\
\hline 8 & $1.60 \mathrm{c}-\mathrm{h}$ & $1.70 \mathrm{c}-\mathrm{h}$ & $1.40 \mathrm{e}-\mathrm{h}$ & $1.57 \mathrm{BC}$ \\
\hline 10 & $0.87 \mathrm{hi}$ & $1.66 \mathrm{c}-\mathrm{h}$ & $1.16 \mathrm{f}-\mathrm{i}$ & $1.23 \mathrm{CD}$ \\
\hline Mean of MS strength & $1.40 \mathrm{~B}$ & $1.69 \mathrm{AB}^{\prime}$ & $1.89 \mathrm{~A}^{\dagger}$ & \\
\hline
\end{tabular}

Means with the same letter in the same column are not significantly different according to Duncan's multiple range test

Effect of BAP concentration, MS strength and their interaction on number of leaves

The effect of BAP concentration on number of leaves was significant. Table (4)The greatest number of leaves was noticed on shoots treated with BAP at 10 medium at 3 quarter strength $(1.89$ and $1.69 \mathrm{~cm}$, respectively). The shortest shoots were
half strength MS medium $(1.40 \mathrm{~cm})$.

The effect of the interaction between BAP concentration and MS strength on shoot length was significant. The longest shoots were a result of combining between MS medium at full strength and $\mathrm{BAP}$ at $3 \mathrm{ppm}(3.63 \mathrm{~cm})$, followed without significant difference by those grown on MS medium at full strength fortified with BAP at 2 ppm $(3.09 \mathrm{~cm})$. MS medium at full strength deprived of BAP gave rise to the shortest shoots $(0.50 \mathrm{~cm})$. ppm, followed with significant difference by shoots subjected to BAP at $8 \mathrm{ppm}$ (16.91 and 14.88 leaves, respectively). The least record in this concern (5.67 leaves) was produced by shoots deprived of BAP (the control treatment). 
The effect of MS strength on number of leaves was significant (Table 4). The highest number was observed on shoots grown on MS medium at either half or 3 quarter strength (12.37 and 12.12 leaves, respectively). MS medium at full strength gave rise to the lowest value in this regard (10.02 leaves).

The same table showed that the effect of the interaction between BAP concentration and MS strength on number of leaves was significant. The greatest number of leaves was found on shoots grown on MS medium at either 3 quarter or full strength, augmented with BAP at $10 \mathrm{ppm}$ (17.33 leaves, for both treatments). On the other hand, MS medium at either half or full strength, both without BAP, in addition the same medium at full strength fortified with BAP at $1 \mathrm{ppm}$ induced the least number of leaves $(4.00,4.33$ and 5.33 leaves, respectively).

Table 4. Effect of BAP concentration, MS strength and their interaction on number of leaves

\begin{tabular}{lcccc}
\hline & & & MS strength & Mean of \\
BAP conc. (ppm) & Half & $\mathbf{3}$ quart. & Full & BAP conc. (ppm) \\
\hline 0 & $4.00 \mathrm{k}$ & $8.67 \mathrm{~h}-\mathrm{j}$ & $4.33 \mathrm{k}$ & $5.67 \mathrm{G}$ \\
1 & $10.03 \mathrm{gh}$ & $9.67 \mathrm{~g}-\mathrm{h}$ & $5.33 \mathrm{k}$ & $8.34 \mathrm{~F}$ \\
2 & $10.67 \mathrm{f}-\mathrm{h}$ & $11.22 \mathrm{e}-\mathrm{h}$ & $6.00 \mathrm{jk}$ & $9.30 \mathrm{EF}$ \\
3 & $13.37 \mathrm{~b}-\mathrm{f}$ & $10.58 \mathrm{f}-\mathrm{h}$ & $6.67 \mathrm{i}-\mathrm{k}$ & $10.21 \mathrm{E}$ \\
4 & $14.25 \mathrm{~b}-\mathrm{d}$ & $12.44 \mathrm{c}-\mathrm{g}$ & $9.44 \mathrm{~g}-\mathrm{i}$ & $12.05 \mathrm{D}$ \\
5 & $13.51 \mathrm{~b}-\mathrm{f}$ & $11.61 \mathrm{~d}-\mathrm{h}$ & $11.61 \mathrm{e}-\mathrm{h}$ & $12.24 \mathrm{CD}$ \\
6 & $14.50 \mathrm{a}-\mathrm{d}$ & $13.33 \mathrm{~b}-\mathrm{f}$ & $14.00 \mathrm{~b}-\mathrm{e}$ & $13.94 \mathrm{BC}$ \\
8 & $14.96 \mathrm{a}-\mathrm{c}$ & $14.26 \mathrm{~b}-\mathrm{d}$ & $15.42 \mathrm{a}-\mathrm{c}$ & $14.88 \mathrm{~B}$ \\
10 & $16.07 \mathrm{a}-\mathrm{b}$ & $17.33 \mathrm{a}$ & $17.33 \mathrm{a}$ & $16.91 \mathrm{~A}$ \\
Mean of MS strength & $12.37 \mathrm{~A}$ & $12.12 \mathrm{~A}$ & $10.02 \mathrm{~B}$ & \\
\hline
\end{tabular}

Means with the same letter in the same column are not significantly different according to Duncan's multiple range test

The effect of MS salt strengths were studyied by many invistagtors. Fadel et al. (2010) proved that halfstrength MS could result in maximum number of shoots and roots of Mentha spicata. Taheri et al. (2015) investigated the effects of different strengths of MS medium (full MS, 1/2 MS, 1/3 MS, 1/4 MS) on nodal segments of Ziziphora persica. They reported that the maximum mean shoot number and shoot length were achieved using 1/2 MS medium. Rezali et al. (2016) observed that maximum shoot number, shoot height, leaf number, of Typhonium flagelliforme (Araceae) were recorded in full-strength MS media, followed by half- and quarter-strength MS media.

On the other contarary, Gnamien et al. (2013) tested different concentrations of MS mineral elements and BAP to regenerate adventitious shoots from the cotyledons of Citrullus lanatus. They found that the medium containing 3/2 strength of MS mineral elements and $1 \mathrm{mg} / \mathrm{l}$ BAP allowed the production of numerous shoots.

Using BAP individually have a positive effect on leaf number. Anis et al. (2010) found that applying 2.82 ppm BAP was effective for inducing multiple shoots of of Balanites aegyptiaca (5.0 shoots/explant) with an average shoot length of $3.7 \mathrm{~cm}$ in $67 \%$ of cultures. Parveen et al. (2010) found that BAP at $0.23 \mathrm{ppm}$ increased avarege shoots 8.20 shoots/explant of Cassia siamea (Senna siamea). Csabai and Mándy (2011) tested the in vitro shoot multiplication of Telekia speciosa (Asteraceae). They reported that the highest proliferation rate was obtained on medium supplemented with $1.13 \mathrm{ppm}$ benzyladenine.Mohamed (2014) showed that using BA at $3 \mathrm{mg} / \mathrm{l}$ significantly increased proliferation rates of taro (Colocasia esculenta) shoots. However, number of shoots decreased as BA increased to 4 or $5 \mathrm{mg} / \mathrm{l}$. Udaya et al. (2016) cultured shoot tips of banana cv. Monthan in MS medium fortified with different BAP concentrations (4, 5 and $6 \mathrm{mg} / \mathrm{l})$. They observed that BAP at $6 \mathrm{mg} / \mathrm{l}$ recorded the highest micro shoot length.

Effect of concentration, MS strength and their interaction on photosynthetic pigments

BAP concentration affected total chlorophyll content. Table (5) shows the highest content was found in shoots treated with BAP at $8 \mathrm{ppm}$, while the lowest was a result of growing shoots in medium containing no BAP at all (0.39 and $0.04 \mathrm{mg} / \mathrm{g}$ f.w., respectively).

MS strength exerted an adverse effct on total chlorophyll content. Table (5) shows as long as medium strength increased from half to 3 quarters and finally to full strength, the total chlorophyll content decreased from 0.30 to 0.19 and finally to $0.17 \mathrm{mg} / \mathrm{g} \mathrm{f.w.}$, respectively.

The interaction between BAP concentration and MS strength had a remarkable influence on total chlorophyll content. The highest content was noticed in shoots grown on MS medium at half strength supplemented with BAP at $8 \mathrm{ppm}$, while the lowest was a result of using MS nedium at full strength deprived of BAP (0.94 and $0.02 \mathrm{mg} / \mathrm{g}$ f.w., respectively).

Table 5. Effect of BAP concentration, MS strength and their interaction on total chlorophyll content (mg/g f.w.)

\begin{tabular}{lcccc}
\hline BAP conc. $(\mathbf{p p m})$ & Half & $\begin{array}{c}\text { MS strength } \\
\text { 3 quart. }\end{array}$ & Full & $\begin{array}{c}\text { Mean of } \\
\text { BAP conc. (ppm) }\end{array}$ \\
\hline 0 & 0.04 & 0.07 & 0.02 & 0.04 \\
1 & 0.09 & 0.07 & 0.08 & 0.11 \\
2 & 0.10 & 0.11 & 0.18 & 0.11 \\
3 & 0.25 & 0.16 & 0.44 & 0.20 \\
4 & 0.23 & 0.25 & 0.23 & 0.31 \\
5 & 0.28 & 0.43 & 0.24 & 0.35 \\
6 & 0.30 & 0.50 & 0.16 & 0.39 \\
8 & 0.94 & 0.06 & 0.08 & 0.18 \\
10 & 0.44 & 0.03 & 0.17 & \\
\hline
\end{tabular}

Means with the same letter in the same column are not significantly different according to Duncan's multiple range test 
Regarding the effect of BAP concentration, MS strength and their interaction on carotenoids content, it was found that using BAP at $6 \mathrm{ppm}$ induced the highest carotenoids content, while using no BAP resulted in the lowest content in the same concern $(0.095$ and 0.004 $\mathrm{mg} / \mathrm{g}$ f.w., respectively).The same table shows that MS strength affected carotenoids content. Half strength MS medium resulted in the highest content, while Full MS medium induced the lowest content of carotenoids (0.046 and 0.026) $\mathrm{mg} / \mathrm{g}$ f.w., respectively.

The influence of the interaction between BAP concentration and MS strength on carotenoids content was noticeable. Table (6) shows the highest content was a result of combining between MS medium at half strength and BAP at $6 \mathrm{ppm}$, while the lowest value was induced on MS medium at 3 quarters without BAP addition (0.107 and $0.003 \mathrm{mg} / \mathrm{g}$ f.w., respectively).

Table 6. Effect of BAP concentration, MS strength and their interaction on carotenoids content (mg/g f.w.)

\begin{tabular}{lcccc}
\hline BAP conc. $(\mathbf{p p m})$ & Half & $\begin{array}{c}\text { MS strength } \\
\text { 3 quart. }\end{array}$ & Full & $\begin{array}{c}\text { Mean of } \\
\text { BAP conc. }(\mathbf{p p m})\end{array}$ \\
\hline 0 & 0.005 & 0.003 & 0.005 & 0.004 \\
1 & 0.015 & 0.008 & 0.014 & 0.012 \\
2 & 0.016 & 0.011 & 0.017 & 0.015 \\
3 & 0.031 & 0.029 & 0.017 & 0.026 \\
4 & 0.046 & 0.039 & 0.033 & 0.040 \\
5 & 0.049 & 0.056 & 0.041 & 0.049 \\
6 & 0.107 & 0.096 & 0.083 & 0.095 \\
8 & 0.093 & 0.023 & 0.015 & 0.044 \\
10 & 0.054 & 0.007 & 0.007 & 0.022 \\
Mean of MS strength & 0.046 & 0.030 & 0.026 & \\
\hline
\end{tabular}

Means with the same letter in the same column are not significantly different according to Duncan's multiple range test

In this concern, Abou Dahab et al. (2005) stated that quarter-strength of MS medium can increase chlorophyll a content in the leaves of Ruscus hypoglossum Rezali et al. (2016) observed that maximum shoot number, shoot height, leaf number, root number, fresh and dry weights of Typhonium flagelliforme (Araceae) were recorded in full-strength MS media, followed by half- and quarter-strength MS media. In contrast, total chlorophyll, chlorophyll a and chlorophyll $\mathrm{b}$ concentration were found highest in quarter-strength MS. Thus, reducing the strength of MS media could increase total chlorophyll, chlorophyll a and chlorophyll b concentrations. de Oliveira et al. (2008) cultured Annona glabra shoots on medium supplemented with different cytokinins to evaluate leaf tissue for photosynthetic pigmentation and chloroplast development. They found that BAP stimulated chloroplast differentiation. Annona glabra plants cultivated in the presence of BAP demonstrated greater chlorophyll $a$ and carotenoid content.

Mukhtar et al. (2009) stated that chlorophyll level increased by BAP treatments on pot grown population of a local variety of cowpea (Vigna unguiculata) Kanannado, with greater increase in the 200 ppm BAP treated plants.

In case of sterilizing Phytolacca dioica bud explants in the establishment stage, it is recommended to use chlorox solution at $35 \%$ for 25 minutes to obtain the highest survival\%, and in the multiplication stage, using MS medium at 3 quarters strength combined with $\mathrm{BAP}$ at $10 \mathrm{ppm}$ will give the highest number of shoots and leaves.

\section{REFERENCES}

Abou Dahab, A.M.; A.M.A. Habib; Y.A. Hosni and A.M.M. Gabr (2005). Effect of MS-salt strength, sucrose and IBA concentration and acclimatization media on Ruscus hypoglossum L. micropropagation. Arab J. Biotechnol., 8(1):141-54.
Anis, M.; A. Varshney and I. Siddique (2010). In vitro clonal propagation of Balanites aegyptiaca (L.) Del. Agroforest. Syst., 78(2):151-158.

Csabai, J; Z. Nagy and A.T. Mándy (2011). In vitro shoot proliferation of Telekia speciosa (Schreb.) Baumg. induced by different cytokinins. Acta Biol Hung., 62(4):453-62.

da Silva, J.A.Te.; B. Winarto; J. Dobránszki and S. Zeng (2015). Disinfection procedures for in vitro propagation of Anthurium. Folia Hortic., 27(1):3-14.

de Oliveira, L.M. ; R. Paiva; J.R.F. de Santana; E. Alves; R.C. Nogueira and F.D.Pereira (2008). Effect of cytokinins on in vitro development of autotrophism and acclimatization of Annona glabra L. In vitro Cell. \& Develop. Biol. - Plant, 44:128.

Dodds, J. H. and L. W. Roberts (1995): Experiments in Plant Tissue Culture - 3rd ed. Press Syndicate of the Univ. of Cambridge, pp. 32-33.

Duncan, D. B. (1955). Multiple range and multiple F tests, Biometrics, 11, 1-42.

Fadel, D.; S. Kintzios; A.S. Economou; G. Moschoupoulou and H.I. Constantinidou (2010). Effect of different strength of medium on organogenesis, phenolic accumulation and antioxidant activity of spearmint (Mentha spicata L.). Open Hort. J., 3:31-5.

Fakhrul, R.H.; J.S. Norrizah; S.S. Jaapar and S.N. Anilizawatima (2014). The effect of potassium concentration on the growth and development of Stevia rebaudiana (Bertoni) and production of stevioside and rebaudioside A. Am. Euras. J. Sustain Agric., 8(2):42-51.

George, E. F. (1993): Plant Propagation by Tissue Culture. Part 1: The Tech. Exegetics Ltd. Edington, Wilts. BA13 4QG, England. 400 pp.

George, E.F; M.A. Hall and G.J.D. Klerk. (2008). Plant Propagation by Tissue Culture. $3^{\text {rd }}$ Edition. Volume 1. The Background. Springer, P.O. Box 17, 3300 AA Dordrecht, The Netherlands. p. 43, 65-66 and 81.

Gnamien, Y.G.; I.A.Z. Bi; Y.J. Kouadio.; Y. Brostaux and J.P. Baudoin (2013). Medium effects on micropropagation and genetic stability of Citrullus lanatus oleaginous type. Agric. Sci., 4(7A):32-44. 
Groll, J.; D.J. Mycock and V.M. Gray (2002). Effect of Medium Salt Concentration on Differentiation and Maturation of Somatic Embryos of Cassava (Manihot esculenta Crantz). Annals of Botany, 89(5):645-648.

InterNet Site 1 (2016): https:// en. wikipedia. org/ wiki/ Phytolacca

Kanwar, J.; S. Godara; M.K. Kaul and A.K. Srivastava (2013). Micro propagation of Carrizo (Citrus carrizo) through mature bud culture. Agric. Sci. Digest, 33(2):109-113.

Khatun, M.M.; T. Tanny; A.M. Razzak; F.M Alam; M. Ekhlas-Uddin; R. Amin and Y. Symthia (2016). Standardization of in vitro Sterilization Procedures for Micropropagation of Ginger (Zingiber Officinale Rosc.). Intl. J. Appl. Biol. and Pharma. Tech., 7(1):131-137.

Mohamed, F.G.E. (2014). Effect of Some Growth Regulators on Micropropagation of Taro Plants (Colocasia esculenta). M. Sc. In Agric. Sci. (Veg.). Dept. Hort., Fac. Agric., Ain Shams Univ.

Mukherjee, P.; N. Husain; S.C. Misra and V.S. Rao (2010). In vitro propagation of a grape rootstock, deGrasset (Vitis champinii Planch.): effects of medium compositions and plant growth regulators. Sci. Hortic., 126(1):13-9.

Mukhtar, F.B.; M. Mohammed and A.H. Ajeigbe (2009). Effect of benzyl amino purine (BAP), coconut milk (CM) and manure applications on leaf senescence and yield in photoperiod sensitive cowpea variety (Kanannado). Afric. J. Plant Sci., 3(7):142-146.

Murashige, T. and Skoog, F. (1962). A revised medium for rapid growth and bioassays with tobacco tissue cultures. Physiologia Plantarum, 15(3): 473-497.
Mustafa, N.S.; R.A. Taha; S.A.M. Hassan and N.S.M., Zaied (2013). Effect of medium strength and carbon source on in vitro shoot multiplication of two Ficus carica cultivars. J. Appl. Sci. Res., 9(4):3068-3074.

Parveen, S.; A. Shahzad and S. Saema (2010). In vitro plant regeneration system for Cassia siamea Lam., a leguminous tree of economic importance. Agroforest. Syst., 80(1):109-116.

Rezali, N.I.; N.J. Sidik; A. Saleh; N.I. Osman and N.A.M. Adam (2016). The effects of different strength of MS media in solid and liquid media on in vitro growth of Typhonium flagelliforme, Asian Pacific J. Trop. Biomed., 914-931.

Sakr, S.S.; S.S. Melad; M.A. El-Shamy and A.E. Abd Elhavez (2011). Propagation of Cerbera odollam Plant by Using Tissue Culture Technique. J. Hort. Sci. \& Orn. Plants, 3(3):276-282, 2011.

Saric M.; R. Kostroi; T. Cupina and I. Geric (1967). Chlorophyll determination Univ. U.Noven Sadu Prakitikum is Kiziologize Bilijaka Beogard, Haucna, Anjiga.

Snedecor, C. W. and W. G. Cochran (1989). Two-way classification, analysis of variance Statistical Methods (8th Ed.). Iowa State Univ. Press Ames, Iowa, U.S.A. p. 254-268.

Taheri, A.; M. Kosari-Nasab and A. Movafeghi (2015). Effects of different strengths of medium on production of phenolic and flavonoid compounds in regenerated shoots of Ziziphora persica. Russian Agric. Sci., 41(4):225-229.

Udaya, C.Y.S.; H.K. Porika; V. Sindhupriya and P.P. Kumar (2016). Enhancing propagation efficiency of banana cv. Monthan (ABB) through micropropagation. Asian J. Hort., 11(1):141-145.

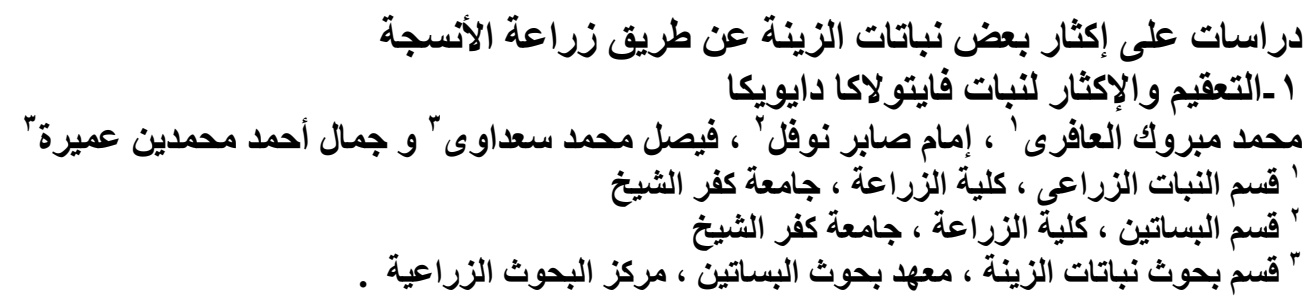

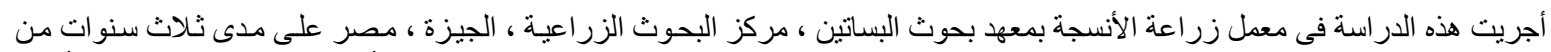

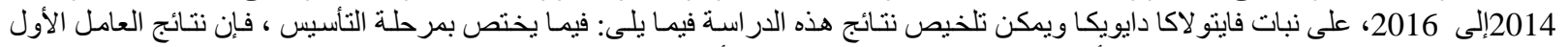

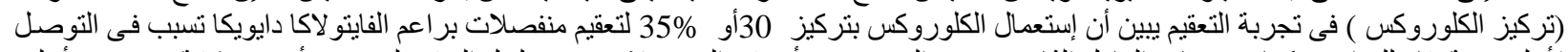

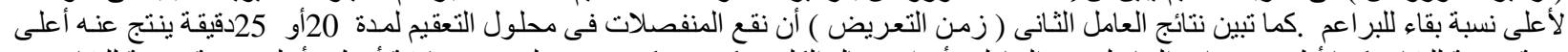

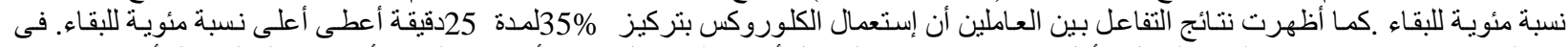

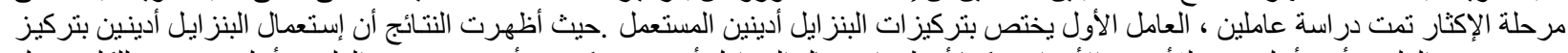

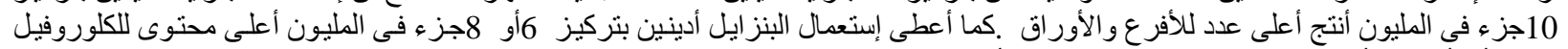

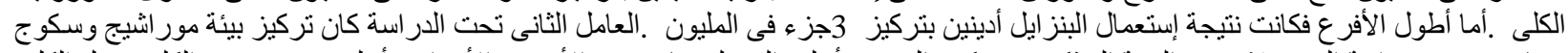

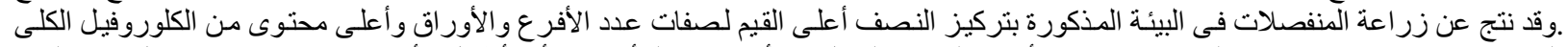

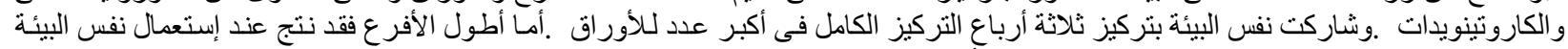

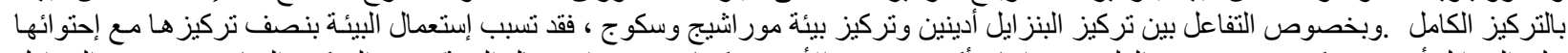

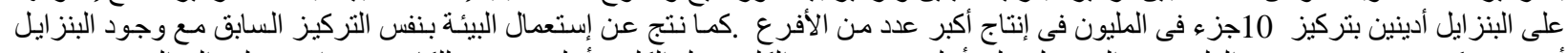

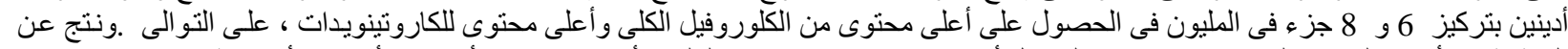

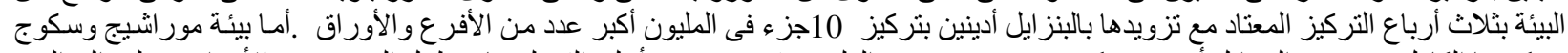

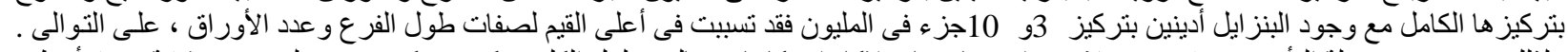

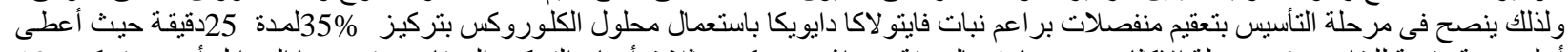

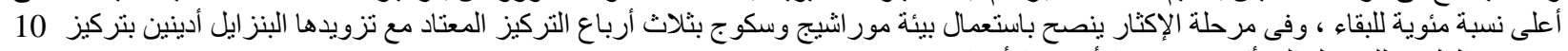

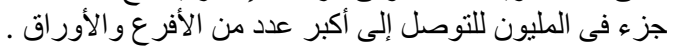

